\title{
POSTCOLONIAL ARABIC FICTION REUISITED، NATURALISM AND EXISTENTIALISM IN GHASSAN KANAFANI'S MEN IN THE SUN
}

\author{
Shadi Saleh Neimneh \\ Hashemite University, Jordan \\ shadistar2@yahoo.com \\ First received: 27 February 2017 \\ Final proof received: 25 September 2017
}

\begin{abstract}
This article looks into the postcolonial Arabic narrative of Ghassan Kanafani to examine its underplayed existential and naturalistic aspects. Postcolonial texts (and their exegeses) deal with the effects of colonization/imperialism. They are expected to be political and are judged accordingly. Drawing on Kanafani's Men in the Sun (1963), I argue that the intersection among existentialism and naturalism, on the one hand, and postcolonialism, on the other, intensifies the political relevance of the latter theory and better establishes the politically committed nature of Kanafani's fiction of resistance. In the novella, the sun and the desert are a pivotal existential symbol juxtaposed against the despicable life led by three Palestinian refugees. The gruesome death we encounter testifies to the absurdity of life after attempts at self-definition through making choices. The gritty existence characteristic of Kanafani's work makes his representation of the lives of alienated characters more accurate and more visceral. Kanafani uses philosophical and sociological theories to augment the political nature of his protest fiction, one acting within postcolonial parameters of dispossession to object to different forms of imperialism and diaspora. Therefore, this article explores how global critical frameworks (naturalism and existentialism) enrich the localized contexts essential to any study of postcolonial literature and equally move the traditional national allegory of Kanafani to a more realist/unidealistic level of political indictment against oppression.
\end{abstract}

Keywords: Ghassan Kanafani; Men in the Sun; postcolonialism; existentialism; naturalism; resistance literature

\begin{abstract}
Men in the Sun and Postcolonial Arabic Literature of Resistance

Recently, the postcolonial Arabic novel has gained increasing importance in literary studies. Writers like Tayeb Salih (Sudan), Ghassan Kanafani (Palestine), Mohammed Abdul Wali (Yemen), among others, have written significant postcolonial works. In particular, Kanafani (1936-1972)—a twentieth-century political activist, journalist, and writer-wrote a committed Palestinian literature of resistance par excellence. According to Al-Madhoon (2012), one characteristic aspect of Kanafani's "literary, journalistic, and political journey was his preoccupation with the broader Palestinian national struggle and all of its demands" (n.p.). In fact, Kanafani was consciously writing a literature of "resistance" as indicated by his 1966 study entitled Literature of Resistance in Occupied Palestine: 1948-1966. This can be justified by the fact that he was writing "within a specific historical context," a postcolonial one "situated within the contemporary national liberation struggles and movements against Western imperialist domination" of many parts in the world and the Middle East in particular (Harlow, 1978 , p.4) after the disaster of 1948 and the establishment of Israel. It is no wonder, then, that his post-al Nakbah literature treats Palestinian
\end{abstract}

identity in terms of "the experience of dispossession and exile" (Rabinowitz, in Sa'di, 2002, p.175).

Kanafani was a spokesperson for the Popular Front for the Liberation of Palestine in the 1960s and founded its official newspaper Al-Hadaf. He wrote within the confines of political activism and Palestinian nationhood. In his fiction, the question of national identity is strongly, and justifiably, present. In the words of Jameson (1986), "a certain nationalism is fundamental in the third world" in countries which "suffered the experience of colonialism and imperialism" (pp. 65-67). The result, for Jameson, is that third-world literary productions can be read as "national allegories" because they project political dimensions in their depiction of personalized lives: "the story of the private individual destiny is always an allegory of the embattled situation of the public third-world culture and society" (p. 69; emphasis original). This same general point is emphasized by Akujobi (2009) when she asserted that "literature and society go hand in hand and for this reason also, it is impossible to talk about third world literature without specific reference to colonialism" (p. 38). Kanafani was committed to this struggle for national liberation and restoring identity. If his fictions are often read within postcolonial and allegorical parameters, it is because his fiction produces "an 
orderly historical but critical interpretation of the Palestinian national plight where characters, speaking for their people, find themselves in search of a national identity which has sense only in space and time" (El-Hussari, 2009, p.1007). Therefore, an attempt to locate the real political and historical value of Kanafani's fiction within the discourse of the novel is a legitimate goal.

In his novella Men in the Sun (1963), Rijal Fi Al-Shams, Kanafani presents the plight of three dispossessed Palestinian refugees seeking an escape from Lebanon to Kuwait to find employment. Subjected to different kinds of hardships and humiliation, the men ironically die just before their arrival in Kuwait having suffocated in the stifling heat inside a water tank truck. In a sense, the novella allegorizes the plight of different generations of young and old Palestinian refugees after the Nakba of 1948. With the loss of land to Israel, the men experienced exile at different levels: they were exiled from their homeland and they were also exiled within Arab states as indicated by border checkpoints. According to Yaqub (2012), therefore, Men in the Sun can be read as an example of "Palestinian journey narratives" whereby characters are representative of Palestinians who are "caught in a liminal space; the state of being 'on the road' is constitutive of their identity" (p. 306). The lives of Palestinian characters are marked by a general state of dislocation and dispossession. In this sense, the novella is also a famous example of a "narrative of departure" (p. 311), a deadly departure though as it leads to their death.

As a postcolonial piece of Arabic literature, the novella is a politicized work that resists and protests against different forms of oppression like discrimination and imperialism. However, what adds to the political weight of such literature of resistance? How does Kanafani negotiate global literary contexts by way of highlighting local and historically specific ones? What makes the national allegories Kanafani consistently wrote in his short stories and novels more militant than traditional national allegories? This article is an attempt to answer such questions by looking at the existential and naturalistic slant of Men in the Sun for the aim of enhancing the political value of Kanafani's literature of resistance. Kanafani in Men in the Sun makes the harsh social and historical circumstances his characters encounter visibly present for the reader, which logically heightens the political import of his fictions. While Kanafani's Return to Haifa (A'id Ila Hayfa, 1970) is an example of a typical allegory about homelessness and loss (with a Palestinian couple losing their child in the war of 1948 and simultaneously losing their family home to Jews) and Umm Saad (1969) is a good mother coming from refugee camps and standing for all Palestinian women supporting their militant children (the "fedayeen"), Men in the Sun is thematically related yet more shocking in its depiction of suffering (which makes it more of a felt allegory rather than a typical one). The novella's extreme social consciousness is a reflection of the radical and revolutionary ideology Kanafani embraced. Like Kanafani's short story "The Stolen Shirt" that depicts - in a socialist fashion - the hunger, deprivation, and cold rainy nights of camp life, Men in the Sun is a gritty, lucid portrayal of suffering and death, and hence a "visceral" rather than a traditional allegory in the abstract. The novella makes the despicable end that the refugees face (having their corpses thrown in a desert rubbishheap) a "just" punishment for the disgrace and humiliation they bring to their lives in trying to find life/dignity outside Palestine.

Speaking of the representation of localized sociopolitical and historical contexts, we should mention that Kanafani experienced al-Nakba of 1948 and lived in Lebanon and Syria as a refugee until his assassination at a young age by the Mossad in a car explosion. His assassination is indicative of the threat his ideological writings posed for his enemies. However, his novella Men in the Sun received mixed reviews. Al-Wadhaf and Omar (2011) read it as a narrative of resistance that tells the story of a nation. Arguing the novella as a national narrative, they contended, "Kanafani had great faith in the need to narrate the story of his nation to resist the Zionist's constant efforts to eradicate Palestine from the global map and to erase the Palestinians from the international community" (p.111). Some views were more critical and more hostile. According to Shaker (2015), for instance, the novella written in 1962, "clearly allegorizes the post-1948 Palestinian refugee experience of deracination and attempts to escape it most starkly" (p. 1). For Khoury (2012), the novella "narrates aspects of the Nakba" and carries a "heavy allegorical aspect" (p. 2). Audebert (1984) argued that Kanafani takes his characters "from slightly different social milieus" and thus "portrays a crosssection of the Palestinian population" (pp.76-93). Therefore, Shaker (2015) contended that the narrative "does not easily map onto a fixed system, or political order, and therefore does not offer a concrete representation of the lives of Palestinian refugees" (p. 1). Still, the novella is a criticism of the defeatism of Arab states and lack of will to fight on the part of Palestinians. Kilpatrick (1999) significantly presented another allegorical level of interpreting the plight of the exiled men in the novella:

On one level it can be read as an exposé of their weakness in preferring the search for material security over the fight to regain their land, and also an attack on the corruption of the Arab regimes that allowed them to suffocate in an airless, marginal world of refugee camps. (p. 11) 
Other accusations are the absence of an immediate Palestinian socio-political context evidenced by the setting being outside Palestine and the ending, in which the Palestinian men are thrown "on the garbage heap" (p. 11). Eid (2013) similarly argued that the solution the refugees took "is only an individualistic one $-\mathrm{a}$ solution that is, geopolitically wrong. In other words, instead of following the correct direction-westward-that leads them from Jordan to Palestine in order to regain their land, they move eastward" (p. 3). For some critics, the men not shouting in the tank or banging also indicates their passive nature and lack of revolutionary potential. In this regard, the men in the sun gave up the fight for their country and simultaneously accepted a quiet death outside Palestine.

Such criticisms of traditional allegory can be rethought, however, in the light of the overlap among the novella's postcolonial aspect and its naturalistic and existential dimensions.

Kanafani lived for a number of years in Kuwait and had feelings of being in exile. It is there that he developed an interest in Marxism and Leninism, establishing a career in journalism. According to Ghirardi (2015), Kanafani was among the first to establish what we know as "resistance literature" written by Palestinian writers "about a people expelled from their land, displaced by the Occidental colonialism" (p. 8). Such writers, for Ghirardi, wrote to criticize the ruling classes and awaken the consciousness of Palestinian people, hoping that a general social revolution in the Arab world would solve the Palestinian issue. In fact, the assassination of Kanafani by the Mossad helped establish his status as a political leader who poses a threat to Zionism due to his realistic portrayals of the daily sufferings of Palestinians in their exilic locales. Kanafani consistently viewed writing as a politicized act with revolutionary or protest potential indicting oppression, complicity, and inaction.

Working at the overlap of naturalism and existentialism, Men in the Sun communicates a protest theme against the dehumanization Palestinian men encounter because of the loss of their original land. It also berates Palestinians who desert their occupied land in search of financial security elsewhere. The sun in the title symbolizes the harsh weather and hardships of the existence of such men. The sun and the desert come to embody the existential precept that "existence precedes essence," which means that "man first of all exists, encounters himself, surges up in the world-and defines himself afterwards" (Sartre, 1969, n.p.). The men are victimized (and even punished) by external natural forces and inner fears and anxieties. Therefore, the novella - an example of politicized and committed literature-works at the intersection of naturalism and existentialism. This nexus of theories and movements enriches the resistance/protest value of such a postcolonial work and creates another level of allegorization, one of experiential concreteness. Although the work relies on modernist and "cinematic" techniques of storytelling with multiple stories and flashbacks that conflate "two separate elements of time and space" (Willows, 2005, p. 18), the political force of the text-i.e. its indictment of political complacency, defeatism, and oppression-is evident and immediate. In order to explicate the contribution of naturalism and existentialism to the political thrust of Men in the Sun, a quick survey of both movements/philosophies might be relevant.

\section{Naturalism and Existentialism in Literature}

As a literary movement, naturalism emerged in the late $19^{\text {th }}$ century and early $20^{\text {th }}$ century (roughly 1890-1915) as a further move away from romantic idealism toward objectivity and detachment. Naturalistic literature depicts a view of the world governed by biological and socioeconomic determinism. Moreover, characters are objectively presented as the victims of the environment, destiny, and drives they cannot control or understand. A sense of fatalism (i.e. lack of free will as opposed to the freedom to choose existentialists' highlight) and scientific objectivity characterizes such naturalistic literature. Harsh realism is what we expect in naturalistic literature because, and in line with the thought of Darwin, Marx, and Freud, characters seek survival in a battleground of socioeconomic forces as well as internal sources of stress. For Zola (1893), the naturalist writer observes and experiments and is a determinist. He says, "We naturalistic novelists submit each fact to the test of observation and experiment, while the idealistic writers admit mysterious elements which escape analysis, and therefore remain in the unknown, outside of the influence of the laws governing nature" (p. 36). On another occasion, Zola asserted, "Naturalism in letters is equally the return to nature and to man, direct observation, exact anatomy, the acceptance and depicting of what is" (p. 114). The novel for naturalists is "impersonal" (p. 125), presenting reality as it is. Zola confirmed this by asserting that naturalistic writers "teach the bitter science of life" and "give the high lesson of reality. Here is what exists; endeavor to repair it" and that they "are but savants, analyzers, anatomists" and their "works have the certainty, the solidity, and the practical applications of scientific works" (pp. 127128). The realism we are after here is not that of dialogue or characters representing different generations or types. In naturalistic fiction, characters cannot dictate their lives as they are victims of factors like heredity, environment, nature, and chance (which are the main differences from existentialism, whereby individuals act out responsibly out of free will). Best characters are lower-class characters who are poor and 
unprivileged. Hence, naturalism was - to a good extent-influenced by both Marxism and evolutionary theories (New World Encyclopedia, "Naturalism", 2015). In naturalistic literature, pessimism is prevalent, and characters face the harshness of life represented in racism, poverty, sexuality, violence, disease, ... etc (Zhang, 2010, p. 196). They seek survival in a hostile, indifferent world. To the extent that exercising free will is merely a deceptive measure against the indifference of the universe, (ontological) naturalism here becomes very close to existentialism in its absurd sense. And the objective representation typical in naturalistic fiction is but a necessary step toward exposing the ugly realities of injustice, poverty, and oppression.

By contrast, existentialism became influential in the second half of the $20^{\text {th }}$ century. Arguably, existentialism emerged out of naturalism. As with naturalism, raw existence is emphasized. Moreover, life is given meaning when we make decisions and act accordingly. As in naturalistic literature, characters in existential literary works are lonely and face an incomprehensible world. This has made some critics reproach existentialism, as Sartre (1969) complains in his lecture "Existentialism Is a Humanism," "for having underlined all that is ignominious in the human situation, for depicting what is mean, sordid or base to the neglect of certain things that possess charm and beauty and belong to the brighter side of human nature". Critics see existentialists as despairing and Godless. Sartre asserted in the same lecture that "ugliness is being identified with existentialism. That is why some people say we are "naturalistic." In this sense, existentialism is a degree or a form of naturalism.

For existentialists, freedom to choose is a source of fear and anxiety, but making choices in an absurd world can only lead to death and meaninglessness. Thus, commitment or engagement is "the basis for an authentically meaningful life, that is, one that answers to the existential condition of being human and does not flee that condition by appeal to an abstract system of reason or divine will” (Stanford Encyclopedia of Philosophy). Existentialism becomes one stage of Marxism, and both intersect with naturalism. Like existentialism, Marxism "makes this necessarily practical orientation of philosophy explicit" (Stanford Encyclopedia of Philosophy). Action and engagement in sociopolitical and historical realities are important in both theories. Racism and exploitation restrict the freedom of individuals to make choices and thus to live authentically. Hence, it is my argument that the combination of both movements, naturalism, and existentialism, enhances the engaged nature of Kanafani's fiction, as the next section further illustrates using his novella Men in the Sun. While naturalism helps Kanafani portray the misery of his characters with a good level of detachment, existentialism helps him to protest against the weakness of his characters against all forces denying them an authentic existence away from their native land. Significantly, both movements allow Kanafani to underscore the material conditions of his characters' lives and the primacy of the sociopolitical context (i.e. existence) over individual consciousness.

\section{Naturalism and Existentialism in Kanafani's Men in the Sun}

In Kanafani's existential fiction, characters live individually without much external help. They make choices to define their being in an irrational universe. His men in the sun embrace their alienated existence as if there is no God or spiritual meaning to life. They make existential choices to leave to Kuwait to transcend the absurdity of life (i.e. to reject the naturalistic determinism of death and suffering); however, the nihilism of death in an open desert is their fate. In that desert, the men do nothing but live anxiously. In trying to get to Kuwait, they are trying to endow that existence with essence and meaning. The most noticeable existential themes in the novella are existential anxiety due to feelings of insecurity about their future and estrangement from their homeland. There is actually an overlap between the raw existence of the blazing sun and the open desert, on the one hand, and the consciousness of characters who have memories of their past life, on the other. Existence/matter is juxtaposed against consciousness/awareness. In other words, the subjective lives of characters and their values are pitted against objective reality and the material realm. This testifies to the overlap between two essential existential dicta: existence and essence. AlHudawi (2003) argued that the novella is "inspired by the Palestinian tragedy and deals with the Palestinian's search for identity in a hostile world, where their very existence was being challenged" (p. 54). As the negation of existence, death acts as an impediment to any meaningful search for identity by Kanafani's men. The men's search for essence, i.e. identity, turns out to be in vain since their existence is precluded in a hostile locale. This interplay between objective existence (the world of matter and nature) and subjective existence (the introspective life of individuals) is itself an example of the extended relationship in the novella between naturalistic and existential ideals. In Men in the Sun, the sun and the desert, i.e. nature or the existence of entities in themselves, exhaust the lives of the dislocated men, i.e. the essence of their lives: who they are, their goals, and their personal traumatic history. It is this conflation of naturalism and existentialism that gets projected in this article.

Said (1993) argued in "Reflections on Exile" that "Exile is strangely compelling to think about but terrible to experience. It is the unhealable rift forced between a human being and a native place, 
between the self and its true home" (p. 173). Kanafani's men in the sun are mentally and physically exiled, feeling lonely, aimless, and bitter. The men are dislocated from their homeland and, simultaneously, they feel and experience this exile, which explicates the dichotomy between the "initself" and the "for-itself." Men in the Sun portrays the sun as a symbol of a hostile, indifferent environment typical in existential works. Kanafani uses matter-of-fact narration and stark realism to drive his themes. Dust and scorching August desert heat have a noticeable presence in the novella. As Abu Qais stares at the sky early in the novella, he sees a black bird that is "circling high up, alone and aimless" (Kanafani, 1999a, p. 22). He too has "the bitter feeling of being a stranger" and is about to weep (p. 22). He has a troubled mind by thoughts about the past and also feels "alien and insignificant" (p. 25). The void that is the sky corresponds to the open space before him, a sheer desert being that is independent of our consciousness. "Those miles of road," Abu Qais observes, speed through "a void, like black eternity" (p. 22). In existential terms, $\mathrm{Abu}$ Qais is encountering the absurdity of the universe. For Camus (1960), "that denseness and that strangeness of the world is the absurd" (1960, p. 11). Stones are "foreign and irreducible to us" and this nature or the landscape "can negate us" (p. 11). Camus contended that the absurd is created out of "this confrontation between the human need and the unreasonable silence of the world" (p. 21) whereby man's desire for order and meaning and "clarity" is encountered by an "irrational" universe (p. 16). The hostile, irreducible landscape negates the solitary existence of Abu Qais. He is fleeing from Iraq to Kuwait across the desert "to find a crust of bread" (Kanafani, 1999a, p. 24). His daughter, we get to know, died of emaciation. He has memories of the smell of damp earth, which he compares to current "heat and dust" of Shatt al-Arab (p. 21). If he gets money, he can send his children to school and buy one or two olive shoots (p. 27). He has only fifteen dinars, but the smuggler insists on taking the whole amount of money. Such naturalistic details about the poverty of Kanafani's characters are simultaneously existential since his men are struggling to survive. On the other side of the Shatt, i.e. in Kuwait, "were all the things he had been deprived of. Over there was Kuwait" (p. 25). Harsh existence in refugee camps makes the men look for a better life whereby the bare necessities are met. Hence, existentialism and naturalism are intertwined in Kanafani's novella in that gritty realism and survival issues are at stake.

Said (1993) has described imperialism in terms of exploring and charting space and geographical locations. Hence, border divisions among Arab states are another form of veiled imperialism just like Israeli manipulation of Palestinian lands by drawing maps and establishing fences and settlements over acquired lands. Both kinds divide people and serve colonialist projects. Such borders are a means of stratification manipulating the existence of the exiled men. Trying to get to Kuwait from Basra, Abu Qais has bitter thoughts about the village he lost and bears the humiliation and hope of an old man of his age with little money but a huge need for a better life of hope. Since land is an integral part of the identity of such a man, the loss of his land, house, and his olive trees means that Abu Qais's whole existence is at risk. Abu Qais left his land ten years ago, his village has fallen "into the hands of the Jews" (Kanafani, 1999a, p. 23). This man is attached to the earth he loves and sniffs ( $p$. 21). The earth gives his existence a meaning, an identity that shapes an otherwise blank being.

Assad is another Palestinian looking for a better life. Like other men, he left a refugee camp and is financially distressed. He is ready to pay fifteen dinars but only after they arrive because when he was smuggled from Jordan to Iraq he was duped (p. 29). Trying to convince the smuggler to take the money after he gets to Kuwait, Assad has a flashback about his previous experience trying to meet the smuggler beyond H4. In such flashbacks, the sun emerges as an existential hero and a natural force victimizing the men: "The sun was pouring flame down on his head, and as he climbed the yellow slopes, he felt he was alone in the whole world" (p. 31). The sun is no less important than other characters. This detached existence of the sun manipulates the daydreams of characters, thus allowing the "in-itself" to subsume the "for-itself." According to Zola (1983), nature as "the spacious world" is given "a place as large as that which we give to man" (p. 232). Assad walked with effort then over the expanse of the desert that was "everywhere" (Kanafani, 1999a, p.31). In All That's Left to You (1966), Kanafani similarly makes the desert an existential ground for the confrontation between the Palestinian hero and an Israeli Soldier who is the occupant of the land. And in Return to Haifa (1970), the return journey after twenty years of loss and exile takes place under a scorching and furious June sun. Therefore, the sun brings to focus the novella's naturalistic and existential slants in a politicized way.

In fact, the novella teems with naturalistic details to evoke the poverty and wretchedness of characters. Assad borrowed money from his uncle and thinks that he will be able to give him the money back and marry his daughter after he returns to his birthplace, Ramleh (Kanafani, 1999a, p.32). Assad answers the fat smuggler when asked about the whereabouts of his stay. that he stays in the Shatt Hotel. The smuggler's answer evokes a naturalistic image: "Ah, the rats' hotel" because it is cheap (p. 33). Once stranded and left by the guide, he is picked off by a man and a woman in a car. She mistakes a rat for a fox. When she asks about the 
abundance of big rats in the desert and about what they eat, the man symbolically answers that they eat "Rats smaller than them" indicating the exploitation of the needy men by greedy ones (p. 35). Assad is another man who tries to escape oppression, tolerating the cold weather of the desert and the blazing sun and bearing the humiliation of sleeping in cheap hotels. The animalistic image is a naturalistic one reminiscent of Darwinian biological determinism. Similarly, big rats are like greedy smugglers who exploit smaller men like Assad. The fact that the smuggler is a fat man supports this symbolic meaning of rats. The novella abounds with other naturalistic details, augmenting the viscerality of its descriptions. The woman Marwan's father married lost a leg during the bombardment of Jaffa, but she owns a house that will make her husband (Marwan's father) leave the mud house of the camp and have a concrete roof (p. 40). Marwan's brother Zakaria also had to leave school and Palestine to support his family and now he got married, while Marwan's family lives in a mud hut (p. 43). Abul Khaizuran tells the men that he smuggles them because he is "miserable"; he wants "more money" and because he finds it difficult "to accumulate money honestly" (p. 56). Kanafani's characters, hence, are trying to escape a harsh existence that negates life. If life in impoverished refugee camps equals death to Kanafani's men, we will ultimately find that life outside their homeland equals death, too, which conflates naturalism and existentialism.

In naturalism, human beings are depicted as passive victims of social and environmental forces. Their struggle against nature is a hopeless one. The men in the story die in the tank without knocking or making noise. Their efforts lead them to death. By choosing to be smuggled to Kuwait, the men are imbuing their life with meaning, but the absurdity of their fate, in existential terms, makes their agonizing journey aimless and useless. Despite what they endured, they die before achieving what they wished for. Marwan, for instance, is a young man also seeking an escape from Basra to Kuwait with no official papers. Only sixteen years old, he was forced to leave school to provide for his family. He loses his honor when he is hit by the fat smuggler for threatening to expose his exploitation. When "the marks of the fingers on his left cheek burned," Marwan "began to digest his humiliation" (p. 37). The economic factor is another source of oppression, which is the Marxist dimension of social stratification contributing to oppression. In this novella, it is also a naturalistic element of deprivation and lowly life.

Marwan is humiliated in the process of seeking a better life in Kuwait. He loses hope as he leaves the fat man's shop: "Crowds of people walked past without paying him any attention. Perhaps it was the first time in his life that he had found himself alone and a stranger in a throng of people like this" ( $p$.
37). Existentialists often employ terms like "horde", "masses", and "crowd" to highlight the social and political dimension of existentialism (Internet Encyclopedia of Philosophy). Nietzsche used the term "the herd" to portray "the bulk of humanity not only as animal, but as docile and domesticated animals" accepting the values of others rather than forging an individual, exceptional existence (Internet Encyclopedia of Philosophy). Authentic existence entails being free to make choices and to accept the anxiety related to that. On the other hand, "inauthenticity manifests itself as deindividuated or faceless" (Internet Encyclopedia of Philosophy). In this sense, existentialism becomes a new possibility for revolutionary politics in fiction. Marwan desperately wants to find work in Kuwait because his family depends on him financially (p. 42). So, he feels responsible for making choices while overwhelmed by anguish. In existential thought, freedom is linked to anguish "because my freedom is in part defined by the isolation of my decisions from any determination by a deity, or by previously existent values or knowledge" (Internet Encyclopedia of Philosophy).

Abul Khaizuran, a Palestinian smuggler, tells Marwan that in Kuwait money is more important than morals (Kanafani, 1999a, p.42). The plan is to have them smuggled by being put in an empty water tank for 10 dinars, which is five dinars less than what the fat smuggler asked for. In such hot August weather, the men are risking their lives and dehumanizing themselves. They accept this way of smuggling because it was cheaper. While they undergo their epic journey across the desert, the sun pours "its inferno down on them without any respite" (p. 52). This sun is the only thing they are sure of; it is an indication of sheer existence rather than essence. The insignificant existence of the men is juxtaposed against the boundless existence of the sun. In other words, the existence of the "in-itself" negates or subsumes the existence of the "for-itself." In a flashback triggered by the blinding sunlight on his windscreen while driving (after a question about being married or not) and a memory of circular light above his head while in hospital, Abul Khaizuran has a memory of his past trauma before ten years. Abul Khaizuran lost his manhood in a humiliating war injury he sustained as a result of an explosion while fighting for his country (p. 53). Therefore, he knows that he had lost both "his manhood and his country, and damn everything in this bloody world" (p. 53). Losing his manhood was tantamount to losing his life, not less (p. 53). This disfigured man has a disability that makes his allegorical significance more immediate and more visceral. Like Jake Barnes in Hemingway's The Sun Also Rises (1926) who sustains a war wound that emasculated him in WWI and comes to embody the lost generation, Abul Khaizuran allegorizes through his personal plight the situation of his country, that 
of dispossession and violation, but the pain of his loss lives with him. And just like Jake, he could not get married or live a normal life. Abul Khaizuran's memory flashes in his head as a result of the glare of the sun on his windshield. The strong existence of the sun is not compatible with his inadequate existence, i.e. his mutilated body and his traumatized psyche.

The experience of smuggling the men into Kuwait is itself an existential adventure. The men fight for mere survival against a blazing sun, a prodigious contender. As he opens the cover for them to enter the tank, Abul Khaizuran advises them to take off their shirts and warns them that "The heat's stifling, terrifying" and that they will "sweat as though [they] were in an oven" (p. 57). He tells them that if they had gone with smugglers they would have seen many skeletons lying on the desert sand (p. 56). He claims that he can tell many scary stories, stories of men "who became like dogs as they looked for one drop of water to moisten their cracked tongues with" (p. 55). The naturalistic details given by Abul Khaizuran augment the existential anguish of Kanafani's men.

In naturalistic fiction, the main conflict is man against an indifferent nature. After the first checkpoint and as the lorry moves through the desert, "The sun blazed brightly and the wind was hot, and carried a fine dust like flour" (p. 60). Feeling the heat, Abul Khaizuran "undid the buttons of his shirt and his fingers touched the thick hair on his chest, which was soaked" (p. 60). When the men get out from the hot tank, their trousers are soaked with sweat and their bare chests are dyed with rust (p. 61). They are exhausted, silent and sullen; and they are passive victims of the sun. They move to the next checkpoint, but the lorry they are in sweeps across the insurmountable expanse of the desert sand and heat (p. 63). As he left the post, Abul Khaizuran had the impression that the tank metal "was about to melt under that fearful sun" (p. 70). The leather seat "burned under him and the glass windscreen was dusty and blazed with the sun's glare" (p.70). This is raw, undifferentiated existence devoid of meaning. The sun, to use the words of Jean-Paul Sartre in Being and Nothingness, represents unconscious being (Being-in-itself) impacting the conscious being of the three men (Being-for-itself) seeking to complete their being and give essence to it out of nothingness by acting in the world. One of the existential principles is being abandoned and thrown into an indifferent world. In this regard, the barren spacious desert suggests this "thrownness" into a vast world. Moreover, Kanafani's text highlights the experience of living under a harsh sun, which is in line with existentialism's concern with the subjective experience of individuals over reason or morality.

Distinguishing between the plenitude of being (the being of phenomena) and consciousness, Sartre
(1969) argued, "Being is. Being is in-itself. Being is what it is" (p. xlii). Sartre further argues: "Since the being of consciousness is radically different, its meaning will necessitate a particular elucidation, in terms of the revealed-revelation of another type of being, being-for-itself..., which is opposed to the being-in-itself" (p. xxxix). Existentially speaking, it is as if the men are in a Godless universe with no means of transcendence. Sartre (1969) argued, "Being-in-itself has no within which is opposed to a without and which is analogous to a judgment, a law, a consciousness of itself" ( $p$. xlii). The men feeling the heat of the sun and the dryness of the desert are conscious of the existence of the in-itself, which-in Sartre's ontology-is the object of consciousness, existing independently of the foritself and without its justification. The "in-itself" like the sun does not abide by human law, nor care for human judgments. Kanafani's men in the sun surrender to this natural force, for the being of the sun consumes their consciously wretched existence. For example, the journey, difficult and humiliating as it is, brings back memories in the characters' minds. Abul Khaizuran has thoughts about the bomb that caused his loss of manhood, but against the shame he felt then he now feels he wants "more money now, more money" (Kanafani, 1999a, p. 64). Assad remembers how a police officer once spat in his face and how he "didn't move as the saliva ran slowly down his forehead and gathered on the tip of his nose in a nasty viscous mess" (p. 64). And the humiliation of this journey is mixed with their dreams of getting education for their children or getting a cottage to live in or buying a shoot or two of olives or getting money or a start in life (pp. 6364). In a sense, the characters' dreams and bitter memories (which constitute the "for-itself") help create the naturalistic atmosphere of the novella.

Apparently, there is a sense of objectivity and detachment in the novella common to both naturalism and existentialism. The narrative perspective does not exclude minute and even ugly naturalistic details. As Abul Khaizuran tries to open the cover of the tank, "A drop of sweat from his forehead fell onto the metal roof of the tank and immediately dried" (p. 71). As for the dead bodies inside, one is "cold and still" with "damp gray hair" (p. 71). In another shocking visceral image, another body is still holding onto the metal support inside the tank with a mouth wide open (p. 72). Abul Khaizuran sweats and trembles, but "he couldn't tell whether he was trembling because of this oil covering his chest and back or whether it was caused by fear" because the "merciless sun" kills them (p. 71). Abul Khaizuran is exhausted and does not know whether to bury them in three graves or throw them in the desert. The dead men are now corpses, but he does not want to leave their bodies: 'He didn't like to think that his companions' bodies should be lost in the desert, at the mercy of birds 
and beasts of prey, and that there would be nothing left of them ... except white bones lying on the sand" (p. 72). This naturalism is mental at the level of his thoughts, but it has an assault effect on the reader. The names of the men who perish under the sun are then withheld, and he throws their "stiff", "firm", and "cold" bodies out (p. 73). Abul Khaizuran thinks that this way the bodies can be "discovered in the morning and buried under official auspices" (p. 73).

One corpse was particularly difficult to remove from the tank. The stark naturalism of the following description is worth considering for its viscerality: "He had great difficulty in prising the hands of the other corpse away from the iron support, but then he pulled it by its legs to the opening and threw it over his shoulder, straight and stiff" (p. 73). Holding them by their feet, Abul Khaizuran "dragged the corpses ... and threw them onto the end of the road, where the municipality's dustcarts usually stopped to dump their rubbish, so that the first driver arriving in the morning would easily have an opportunity to see them" (p. 73). So, the men are left without burial by the garbage after having their money and personal items taken from them. When we find the men dead, this horrific ending stifles us and makes us live through this cramped life of Kanafani's characters. The sordid realism of the ending consolidates the existential futility of a life in disgrace away from one's country. Moreover, there is a sense of determinism associated with the inevitably negative repercussions of racism. Kanafani's employment of naturalism and existentialism within this novella, hence, is part of an ideological framework of protest against oppression. However, the political and historical value of the text is embedded in the autonomous fictional discourse he is writing within. His language might repel us, but this should heighten the politicized potential of his writing through a potentially higher level of sympathy with his men victimized by the sun. Alternatively, the viscerality of such descriptions makes Kanafani's indictment of political defeatism and complacency stronger as trying to start a life outside one's homeland is an extreme form of betrayal when that land is occupied.

Abul Khaizuran could not understand why the men did not knock on the sides of the tank to seek help before they died (p. 74). One would think of the symbolic meaning of this last question the novella raises. This might have been a futile act on the part of the men on more than one level: first of all, they — as the subaltern - might have knocked but no one heard them or bothered to listen. Second, knocking would have betrayed them to the police. In both cases, knocking or not knocking, death is the absurd but inevitable conclusion. Third, the men may have lost the will to live due to the humiliation they continually received. They were dead in life, in a sense, from the moment they left their land to seek life elsewhere. A life with no freedom or dignity is not much different from the disgrace of death. The death of the men is an indication of the absurdity of existence, but it is also a protest against a similar death the men could have faced in the constricted life of refugee camps or at the hands of the enemy soldiers. In fact, the airless desert weather and the cramped tank atmosphere might correspond to the overcrowded refugee camp life the men were trying to flee.

The death of the men signifies the triumph of the sun as an existential and natural force or the insignificance of their being compared to the plenitude of the natural existence of the sun; "This desert was like a giant in hiding, flogging their heads with whips of fire and boiling pitch. But could the sun kill them and all the stench imprisoned in their breasts?" (p. 65). The sun is made their hell on earth while the tank is seen by them as a "terrible prison" (p. 65). But barbed wire fences were another kind of prison for them. They had to cross gates and barbed-wire fences of frontier posts to get to Kuwait in order to live, but the price was their deathwhich is an ironic twist on the amount the smuggler charged them. Hence, Kanafani makes it clear that the dislocated men will have neither honor nor dignity nor life outside their home country. This ugly death the men face is Kanafani's ultimate comment on the fate of those who leave their land to pursue a supposedly "better" life elsewhere.

\section{Conclusion: Revisiting Postcolonial Arabic Literature of Resistance}

Men in the Sun encompasses many naturalistic and existential themes. Both philosophies of human life, existentialism, and naturalism overlap in this novella. The novella, like other Kanafani fictions, "reveals an equal commitment to the Palestinian cause, and "a development on both the political and the artistic levels" (Kilpatrick, 1999, p.11). In other words, Kanafani strikes a balance between political and artistic demands, expressing political statements while retaining artistic freedom. This article has been an attempt to reclaim the former. Kanafani communicates many messages at once: individuals not united into a nation cannot achieve anything. They grow weaker and seek individual salvation, only to wretchedly die in the process. Moreover, the option of fighting may not be necessarily better. This option Abul Khaizuran used also led to his emasculation. When the existential odds are great, fighting is tantamount to lack thereof. Such political statements are given by Kanafani in a matter-of-fact allegory that tackles the harsh realities and material conditions of humiliation and death face to face and without the metaphorical distance of a typical allegory. The result is one of experiential concreteness, i.e. a realist approach detailing the suffering of his men in the sun and effectively communicating this misery to the reader. 
The Zionist occupation of Palestine and the complacency of Arab governments contributed to the ironic death of the three Palestinian refugees in the sun. The men do leave their land, but they are driven by forces beyond their control, like poverty and lack of chances or official paperwork. Some like Ustaz Selim stayed and fought and died for the national cause, but that was the older generation. The younger one's lot was no better. And the story is an allegory about losing the land and the deception Palestinians encountered. Abul Khaizuran, for example, stands for weak political leaders lacking courage. The men with no graves are also with no homeland. But Kanafani's allegory is more of a visceral allegory of death, one about stiff and cold bodies in death and poor bodies in life. Traditionally, allegory is detached from objective reality. It "rejects that assumption of an imminent meaning to human existence" as a basis for "traditional art" in favor of transcendence as "the negation of any meaning immanent in the world or the life of man" (Lukacs, 1963, n.p.). It is no wonder, hence, that Walter Benjamin viewed allegories as ahistorical, holding the analogy that they are in the intellectual realm what ruins are in the real world: "What ruins are in the physical world, allegories are in the world of the mind" (in Lukacs, 1963, n.p.). The immediacy of the materiality of suffering and death depicted in Kanafani's novella counters traditional allegorical abstraction and distance. Apparently, the viscerality of Kanafani's allegory underscores the novella's ultimate message about the fate of those who desert their homeland and try to find dignity elsewhere. At least, there might be more dignity to dying in one's country even if the odds are great.

In brief, Kanafani's novella carries a protest message not in a traditional sense (i.e. general or idealized sense) but in another allegorical level, a visceral one in its shocking naturalistic end about the three corpses being thrown on a garbage heap in a desert dump after a horrible death inside a closed water tank. In this unconventional allegory, it is the bodies of the Palestinian men that serve as a witness to suffering. As with other political contexts of strife and tension across the globe, "the body re-emerges as a historical site of oppression and resistance" (Neimneh, 2014, p. 692). If Kanafani wanted to communicate to us the impossibility and the meaninglessness of life for Palestinians away from their motherland, i.e. the stifling nature of life away from one's home, he compelled that recognition from us via the existential and naturalistic details of his story. The assault effect of his fiction is enough to make us feel repelled at the ugly end his characters in the sun face. Kanafani's politics is one of shame and aversion through an act of mourning, a relentless preoccupation with the Palestinian issue at ontological and naturalistic levels where survival/existence and death constantly clash.
Viewed existentially and naturalistically, Kanafani's resistance fiction-which depicts the gruesome effects of the real-acquires a new force and another level of commitment through its forceful effect on the reader.

\section{REFERENCES}

Akujobi, R. (2009). Hunger and waiting in ThirdWorld Literature. Lagos Papers in English Studies, 4, 38-44.

Al-Hudawi, S. H. (2003). Re-discovering identity: A study on the theme of resistance in Ghassan Kanafani's selected novels (Unpublished Master's Thesis). Universiti Teknologi Malaysia, Malaysia.

Al-Madhoon, R. (2012). Ghassan Kanafani: The symbol of the Palestinian tragedy. Trans. Nehad. Retrieved from http://www.jadaliyya.com/pages/index/6885/g hassan-kanafani_the-symbol-of-thepalestinian-tra

Audebert, C. F. (1984). Choice and responsibility in 'Rijal Fi Al-Shams.' JSTOR: Journal of Arabic Literature, 15, 76-93.

Al-Wadhaf, Y.H \& Omar, N. (2011). Narrating the Nation and its Other: The emergence of Palestine in the postcolonial Arabic novel. $3 L$ : The Southeast Asian Journal of English Language Studies, 17, 109-119.

Camus, A. (1960). The myth of Sisyphus and other essays. Trans. Justin O'Brien. New York: Vintage.

Eid, H. (2013). Men in the Sun: The Palestinian diaspora. New Academia, 2(4), 1-9.

El-Hussari, I. A. (2009). The symbolic conflation of space and time in Ghassan Kanafani's Novel Ma Tabaqqa la-kum (All That's Left to You). Middle Eastern Studies, 45(6), 1007-1014.

"Existentialism." Internet Encyclopedia of Philosophy. Retrieved from http://www.iep.utm.edu/existent/22/10/2 015 .

“Existentialism." Stanford Encyclopedia of Philosophy. Retrieved from http://plato.stanford.edu/entries/existent ialism/

Ghirardi, F. (2015). In Memoriam: Ghassan, Palestinian novelist and political activist. The New Arab. Retrieved from: https://www.alaraby.co.uk/english/artsandcultu re/2015/4/16/in-memoriam-ghassan-kanafanipalestinian-novelist-and-political-activist

Harlow, B. (1978). Resistance literature. New York: Methuen.

Jameson, F. (1986). Third-world literature in the era of multinational capitalism. Social Text, 15, 65-88. 
Kanafani, G. (1970). Return to Hayfa (A'id Ila Hayfa). Retrieved from http//www.kataebbabuali.ps

Kanafani, G. (1999a). Men in the Sun and Other Palestinian Stories. Trans. Hilary Kilpatrick. Boulder: Lynne Rienner.

Kanafani, G. (1999b). "Letter from Gaza." In Men in the Sun and Other Palestinian Stories (pp. 111-115.). Trans. Hilary Kilpatrick. Boulder: Lynne Rienner.

Khoury, E. (2012). Rethinking the Nakba. Critical Inquiry, 38, 1-18.

Kilpatrick, H. (1999). Introduction. In Men in the Sun and Other Palestinian Stories (Ghassan Kanafani) (pp. 9-15). Trans. Hilary Kilpatrick. Boulder: Lynne Rienner.

"On the Life of a Rebel: Ghassan Kanafani." (2015). Daily News Egypt. Retrieved from http://wwwdailynewsegypt.com/author/d aily-news-egypt/

Lukacs, G. (1963). The ideology of modernism. In The Meaning of Contemporary Realism, trans. John and Necke Mander London: Merlin Press. Retrieved from "Naturalism." New World Encyclopedia. Retrieved from http://www.newworldencyclopedia.org/e ntry/Naturalism_(literature)

Neimneh, S. (2014). The visceral allegory of Waiting for the Barbarians: A postmodern rereading of J. M. Coetzee's apartheid novels. Callaloo: A Journal of African Diaspora, 37(3), 692-709.
Sa'di, A. H. (2002). Catastrophe, memory and identity: Al-Nakbah as a component of Palestinian identity. Project Muse: Israel Studies, 7(2), 175-198.

Said, E. (1993).Culture and imperialism. London: Chatto \& Windus.

Sartre, J.P. (1969). Being and nothingness: An essay on phenomenological ontology. Trans. Hazel E. Barnes. London: Methuen.

Shaker, N. (2015). 'Men in the Sun' and the modern allegory. The Postcolonialist. Retrieved from http://www.postcolonialist.com/contribut or/nadeen-shaker/

Willows, P. (2005). Gestalt psychology, semiotics and the modern Arabic novel." AS/SA, 15, 1423.

Yaqub, N. (2012). Utopia and dystopia in Palestinian circular journeys from Ghassan Kanafani to contemporary film. Middle Eastern Literatures, 15(3), 305-317.

Zhang, X. (2010). On the influence of naturalism on American literature. English Language Teaching, 3(2), 195-198.

Zola, E. (1893). The experimental novel and other essays. Trans. Belle M. Sherman. New York: The Cassell Publishing Co. 